\title{
Program Gerbang Desa Saburai dan Pengentasan Desa Tertinggal Di Provinsi Lampung
}

\section{Saburai Village Gate Program And the Elimination of Underdeveloped Villages in Lampung province}

\author{
$\operatorname{Ambya}^{1 *}$ \\ ${ }^{1}$ Universitas Lampung \\ *E-mail : ambya.mahmud@gmail.com
}

\begin{abstract}
This study aims to evaluate and analyze the Saburai Village Gate Program implemented by the Lampung provincial government in 2015-2018 with the aim of alleviating underdeveloped villages. This program is expected to be a model for improving the status of the village based on empowerment. The method used in this research is panel data analysis using significance tests, and the Random Effect Model (REM) is the best model to use. The results obtained show that the variable of community direct assistance and non-government funding has a negative and significant effect on the number of disadvantaged villages. Where the increase in direct assistance from communities and non-governmental organizations is able to reduce the number of underdeveloped villages. In the future, this model can be developed as a tool of local government policy in order to improve public services by providing rural infrastructure.
\end{abstract}

Keywords: Community Direct Aid, Self-Help Funds, Random Effect Model.

Disubmit : 19 Maret 2020, Diterima:10 April 2020, Disetujui : 19 Mei 2020

\section{PENDAHULUAN}

Pembangunan nasional bersifat multidimensional, sehingga dengan adanya pembangunan nasional diharapkan tercapai pemerataan di berbagai sektor, bidang maupun wilayah, (Ali 2009). Arah kebijakan pembangunan yang didasarkan pada Nawa Cita antara lain meningkatkan pertumbuhan ekonomi yang inklusif dan berkelanjutan, mempercepat pembangunan infrastruktur untuk pertumbuhan dan pemerataan, dan meningkatkan pengelolaan dan nilai tambah sumber daya alam (SDA) yang berkelanjutan (Bappenas RI 2015). Prioritas pembangunan terhadap suatu wilayah yang unggul menyebabkan kesenjangan atau ketimpangan pembangunan antar wilayah. Sebagaimana Sjafrizal (2008) menyatakan bahwa setidaknya ada lima faktor yang menyebabkan kesenjangan atau ketimpangan pembangunan antar wilayah. Kelima faktor tersebut antara lain perbedaan kandungan sumberdaya alam, perbedaan kondisi geografis, mobilitas barang dan jasa, konsentrasi kegiatan ekonomi, dan perbedaan alokasi dana pembangunan antar wilayah.

Orientasi kewilayahan membuka peluang terjadinya pemerataan pembangunan yang lebih merata di seluruh Indonesia. Pembangunan kawasan perdesaan secara komprehensif merupakan faktor penting bagi pembangunan daerah, pengentasan kemiskinan, dan pengurangan kesenjangan antar wilayah. (Alamsyah 2011) diperkirakan lebih dari tiga perempat penduduk Indonesia tinggal di daerah pedesaan. Sehingga selalu memunculkan masalah kesenjangan antara desa dan kota, kemiskinan, dan pengangguran dimana hal tersebut selalu dijadikan indikator keberhasilan pembangunan. Pengentasan kemiskinan harus pula berarti 
peningkatan mutu hidup. Sementara pengangguran dan keterbelakangan menyebabkan sebuah desa menjadi tertinggal.

Isu trategis pembangunan desa dan kawasan perdesaan yaitu rendahnya kualitas hidup masyarakat di perdesaan, kemiskinan disebabkan oleh keterisolasian wilayah. Pembangunan sarana dan prasarana di desa dan kawasan perdesaaan yang memiliki keterbatasan. Penyediaan infrastruktur, pendidikan, kesehatan, listrik, transportasi, dan telekomunikasi sangat terbatas. Berikutnya isu keberdayaan dan kemandirian masyarakat perdesaan yang disebabkan oleh faktor ekonomi maupun non ekonomi. Demikian juga dengan tata kelola pemerintahan desa dan kelembagaan kemasyarakatan yang dengan disahkannya UU No. 6 Tahun 2014 tentang Desa, pemerintah desa semakin dituntut untuk semakin aktif, efisien, dan akuntabel. Serta belum maksimal pemanfaatan sumber daya alam dan lingkungan yang ada secara maksimal dan berkelanjutan.

Pada tahun 2014 Badan Pusat Statistik (BPS) Provinsi Lampung telah menetapkan adanya 380 Desa kategori Tertinggal yang masih sangat memerlukan perhatian khusus. Sejalan dengan Agenda Nawa Cita, "membangun Indonesia dari pinggiran dengan memperkuat daerah dan desa dalam Negara Kesatuan" dan pencapaian visi Gubernur Lampung, Lampung Maju dan Sejahtera, Tahun 2019. Pemerintah Provinsi Lampung memandang perlu mengembangkan kebijakan program untuk mendorong adanya program pembangunan dari, oleh, dan untuk masyarakat di lokasi-lokasi desa tertinggal dengan memanfaatkan potensi dan pranata sosial khas yang ada di Provinsi Lampung. Konsep pembangunan berbasis pada masyarakat (community-based development) ini menjadi sangat relevan untuk diimplementasikan karena berbeda dengan konsep pembangunan pada umumnya, karena titik temu dari konsep pembangunan ini lebih mengacu kepada pelayanan yang berbasis pada masyarakat (community-based human services).

Kebijakan program pembangunan merupakan suatu model pembangunan berbasis kehasan masyarakat lampung. Program pemberian bantuan dana stimulan tersebut diberi nama Program Gerakan Membangun Desa Sai Bumi Ruwa Jurai yaitu suatu gerakan yang dilakukan dari, oleh, dan untuk masyarakat Provinsi Lampung. Progran sebagai upaya mempercepat pembangunan infrastruktur desa bagi pengembangan otonomi masyarakat desa yang berstatus tertinggal. Daerah tertinggal adalah daerah kabupaten yang relatif kurang berkembang dibandingkan daerah lain dalam skala nasional, dan berpenduduk yang relatif tertinggal (Badan Perencanaan Pembangunan Nasional 2004). Sedangkan menurut Peraturan Menteri PDT nomor 1 tahun 2005 tentang Strategi Nasional Pembangunan Daerah Tertinggal, daerah tertinggal didefinisikan sebagai daerah kabupaten yang masyarakat serta wilayahnya relatif kurang berkembang dibandingkan dengan daerah lain dalam skala nasional.

Program Gerakan Membangun Desa Sai Bumi Ruwai Jurai atau disebut dengan Gerbang Desa Saburai yang diresmikan sejak tahun 2015 yang tertuang dalam Peraturan Gubernur nomor 37 tahun 2015 tentang Program Membangun Desa Sai Bumi Ruwa Jurai Tahun 2015-2018. Diawal penyelenggaraannya, program pemerintah Provinsi Lampung memberikan dana bantuan kepada 30 desa tertinggal sebesar 100 juta rupiah tiap desa, dana tersebut dimaksudkan untuk memberikan stimulan bagi desa, demi tercapainya desa yang makmur dan sejahtera, tertinggal dan transmigrasi. Program Gerbang Desa Saburai adalah salah satu program unggulan di Provinsi Lampung dalam rangka membangun desa dan mengentaskan desa tertinggal.

Berbagai upaya pemerintah melalui program-program nasional untuk mengentaskan kemiskinan di pedesaan telah banyak dilakukan, seperti Program Inpres Desa Tertinggal (IDT), Program Pengembangan Kecamatan (PPK), Program Pembangunan Prasarana Pendukung Desa Tertinggal (P3DT), dan lainnya, belum dapat memberikan hasil maksimal mengentaskan desa berstatus tertinggal. Bersandar pada pengalaman program-program tersebut maka di pandang perlu untuk melalukan evaluasi dan analisis terhadap program tersebut yang berbasis pada bantuan langsung masyarakat dan swadaya masyarakat terhadap pengurangan desa tertinggal di Provinsi Lampung. 


\section{METODE PENELITIAN}

Data yang digunakan adalah jumlah desa tertinggal yang diperoleh dari Badan Pusat Statistik (BPS) Provinsi Lampung. Jumlah Bantuan langsung yang digelontorkan pemerintah, serta Swadaya masyarakat yang diperoleh dari pengelola program yaitu Dinas Pemberdayaan Masyarakat Desa (PMD) dengan periode waktu tahun 2015-2018. Studi ini menggunakan analisis panel data atau pooled data, dengan pertimbangan data runtut waktu (time series) dan data silang (cross section) terbatas. Pengolahan data menggunakan program Eviews 9 yang diawali dengan penentuan model pendekatan yang baik antara: common effect, fixed effect, dan random effect. Analisis dalam penelitian ini menggunakan variabel bebas yaitu dana Bantuan Langsung Masyarakat (BLM), dan Swadaya (SDY) masyarakat. Model matematis yang dibentuk yaitu model regresi sebagai berikut:

$\mathrm{JDT}_{\mathrm{it}}=\beta_{0}+\beta_{1} \mathrm{BLM}_{\mathrm{it}}+\beta_{2} \mathrm{SDY}_{\mathrm{it}}+\varepsilon_{\mathrm{it}}$

dimana:

$\mathrm{JDT}_{\text {it }} \quad=$ Jumlah Desa Tertinggal

$\beta_{\mathrm{i}} \quad=$ Konstanta

$\mathrm{BLM}_{\mathrm{it}}=$ Bantuan Langsung Masyarakat

$\mathrm{SDY}_{\mathrm{it}}=$ Swadaya Masyarakat

$\varepsilon_{\text {it }} \quad=$ error term

Pemilihan model yang baik angara random effect (REM) atau fixed effect (FEM) dilakukan tahapan pengujian yang diawali dengan Uji Signifikansi Fixed Effect dengan Uji Chow dan hasilnya menunjukkan bahwa nilai Prob. Cross-section F sebesar 0.8990 lebih besar dari taraf nyata $(\alpha) 5$ persen, $(0,8990>0,05)$ maka $\mathrm{H}_{0}$ diterima sehingga dapat disimpulkan bahwa metode Common Effect (CEM) lebih baik dari pada Fixed Effect (FEM). Tahap selanjutnya dilakukan Uji Signifikansi Random Effect melalui Uji Hausman dan hasilnya menunjukkan bahwa nilai p-value sebesar 0.1350 lebih besar dari taraf signifikansi $\alpha$ sebesar 5\% $(0,05)$ atau tidak signifikan. Maka dapat disimpulkan bahwa metode random effect (REM) lebih baik digunakan daripada metode fixed effect (FEM) dalam penelitian ini. Untuk lebih menyakinkan maka dilakukan Uji Signifikansi Panel Least Squares (Uji Breusch-Pagan LM) diperoleh hasil bahwa nilai probabilitas Breusch-Pagan BP) sebesar 0,0000 lebih kecil dari taraf signifikansi 5\% menunjukkan bahwa nilai probabilitas (p-value) < 0,05 maka disimpulkan bahwa metode Random Effect Model (REM) lebih baik dari pada metode Common Effect Model (CEM).

\section{HASIL DAN PEMBAHASAN}

Evaluasi Output Secara keseluruhan Program Gerbang Desa Saburai dilaksanakan pada 393 desa yang tersebar di 13 kabupaten, secara lengkap cakupan wilayah program Gerbang Desa Saburai dapat disajikan pada tabel berikut ini :

Tabel 1. Sasaran lokasi Program Gerbang Desa Saburai Tahun 2015 - 2018

\begin{tabular}{clccccc}
\hline \multirow{2}{*}{ No } & \multirow{2}{*}{ Kabupaten } & \multicolumn{3}{c}{ Tahun } & Jumlah \\
\cline { 3 - 7 } & & 2015 & 2016 & 2017 & 2018 \\
\hline 1 & Lampung Barat & 3 & 8 & 18 & 38 & 38 \\
\hline 2 & Lampung Selatan & 2 & 4 & 12 & 14 & 14 \\
\hline 3 & Lampung Tengah & 2 & 4 & 7 & 8 & 8 \\
\hline 4 & Lampung Utara & 2 & 19 & 35 & 50 & 50 \\
\hline 5 & Mesuji & 2 & 8 & 22 & 32 & 32 \\
\hline
\end{tabular}

Volume 4, Nomor 1, Tahun 2020 Hal 36 


\begin{tabular}{clccccc}
\hline 6 & Pesawaran & 2 & 6 & 20 & 21 & 21 \\
\hline 7 & Pesisir Barat & 3 & 11 & 29 & 58 & 57 \\
\hline 8 & Pringsewu & 2 & 5 & 5 & 5 & 5 \\
\hline 9 & Tanggamus & 3 & 12 & 51 & 101 & 101 \\
\hline 10 & Tulang Bawang barat & 2 & 6 & 12 & 14 & 14 \\
\hline 11 & Tulang Bawang & 2 & 5 & 15 & 18 & 18 \\
\hline 12 & Way Kanan & 3 & 8 & 20 & 31 & 31 \\
\hline 13 & Lampung Timur & 2 & 4 & 4 & 4 & 4 \\
\hline & Jumlah & 30 & 100 & 250 & 393 & 393 \\
\hline
\end{tabular}

Sasaran lokasi Program Gerbang Desa Saburai dilakukan pada tahun 2015 - 2018 sebanyak 393 desa tertinggal di Provinsi Lampung. Pada tahun 2015 program Gerbang Desa Saburai dilakukan pada 30 desa yang merupakan pilot project Program ini. Pada tahun 2016 dilakukan pada 100 desa, tahun 2017 dilakukakan pada 250 desa dan pada tahun 2018 program Gerbang Desa Saburai dilakukan pada 393 di Provinsi Lampung.

Partisipasi masyarakat dalam menerima dan memanfaatkan hasil pembangunan pada Program Gerbang Desa Saburai pada tahun 2015-2018 diwujukan dengan keterlibatan dalam proses perencanaan, pelaksanaan berbasis pada kelompok kerja yang di sebut pokmas. Sehingga jenis prasarana yang dibangun memang yang dibutuhkan oleh masyarakat, jenis kegiatan dianggap bermanfaat seperti jalan onderlagh, sumur bor, jalan rabat beton, drainase, jembatan dan talud. Hal ini tercermin pada waktu pemilihan jenis prasarana yang akan dibangun, masyarakat dilibatkan secara langsung dalam pemilihan prasarana yang akan dibangun, sehingga prasarana yang dibangun sesuai dengan kebutuhan masyarakat dan tepat sasaran. Keseriusan masyarakat dalam berpartisipasi dicerminkan tingginya swadaya masyarakat dalam pelaksanaan dan pelestarian pembangunan. Swadaya masyarakat dalam pelaksanaan dapat dilihat dari besarnya respon masyarakat yang ikut berpartisipasi dalam menyumbangkan tenaga , material, atau biaya.

Tabel 2. Sumber Pendanaan dan persentase Swadaya Masyarakat Program Gerbang Desa Saburai Tahun $2015-2018$

\begin{tabular}{lrrrr}
\hline \multicolumn{1}{c}{ Sumber Dana } & \multicolumn{3}{c}{ Tahun (juta) } \\
\hline APBD & \multicolumn{1}{c}{2015} & 2016 & \multicolumn{1}{c}{2017} & \multicolumn{1}{c}{2018} \\
\hline Swadaya Masyarakat & 3.000 & 30.000 & 60.000 & 59.320 \\
\hline Jumlah Biaya & 330 & 3.600 & $7.742,4$ & $10.178,4$ \\
\hline Swadaya (\%) & 3.330 & 33.600 & 67,7724 & $69.498,4$ \\
\hline
\end{tabular}

Sumber : diolahan

Sumber dana yang berasal dari swadaya masyarakat cukup menggembirakan, pada tahun 2015 sebesar $11.00 \%$, selalu meningkat dan pada tahun 2018 menjadi 17.00\%. Partisipasi masyarakat dalam pelaksanaan Program Gerbang Desa Saburai ini mengalami peningkatan tiap tahunnya seiring meningkatnya jumlah desa yang mendapatkan Program Gerbang Desa Saburai. Partisipasi swadaya masyarakat dapat berupa tenaga yang kerja dihitung dengan Hari Orang Kerja (HOK) yang dikonversi dalam rupiah (swadaya masyarakat), selain itu swadaya masyarakat juga dapat dilihat dari sumbangan yang diberikan masyarakat berupa material (semen, pasir), ini dilakukan bagi masyarakat yang ada di daerah tertinggal, karena tidak semua masyarakat di daerah tertinggal dikatakan miskin atau tidak mampu, ada sebagian masyarakat yang mampu memberikan 
swadaya berupa material dan ada masyarakat mampu menyumbangkan lahan nya untuk pembukaan badan jalan yang memperlancar

Hasil evaluasi yang dilakukan pada tahun 2015 - 2018 dapat disimpulkan bahwa Program Gerbang Desa Saburai mendekati tujuan utama yaitu meningkatnya kesejahteraan dan kesempatan kerja masyarakat miskin di pedesaan dengan mendorong kemandirian dalam pengambilan keputusan dalam pengelolaan pembangunan. Hal ini ditandai dengan setelah program tersebut selesai dapat dilihat adanya peningkatan status desa dari tertinggal menjadi kurang berkembang, berkembang, dan maju.

Keberhasilan dalam mencapai tujuan Program Gerbang Desa Saburai juga dapat dilihat dari evaluasi dari status desa yaitu sebagai berikut:

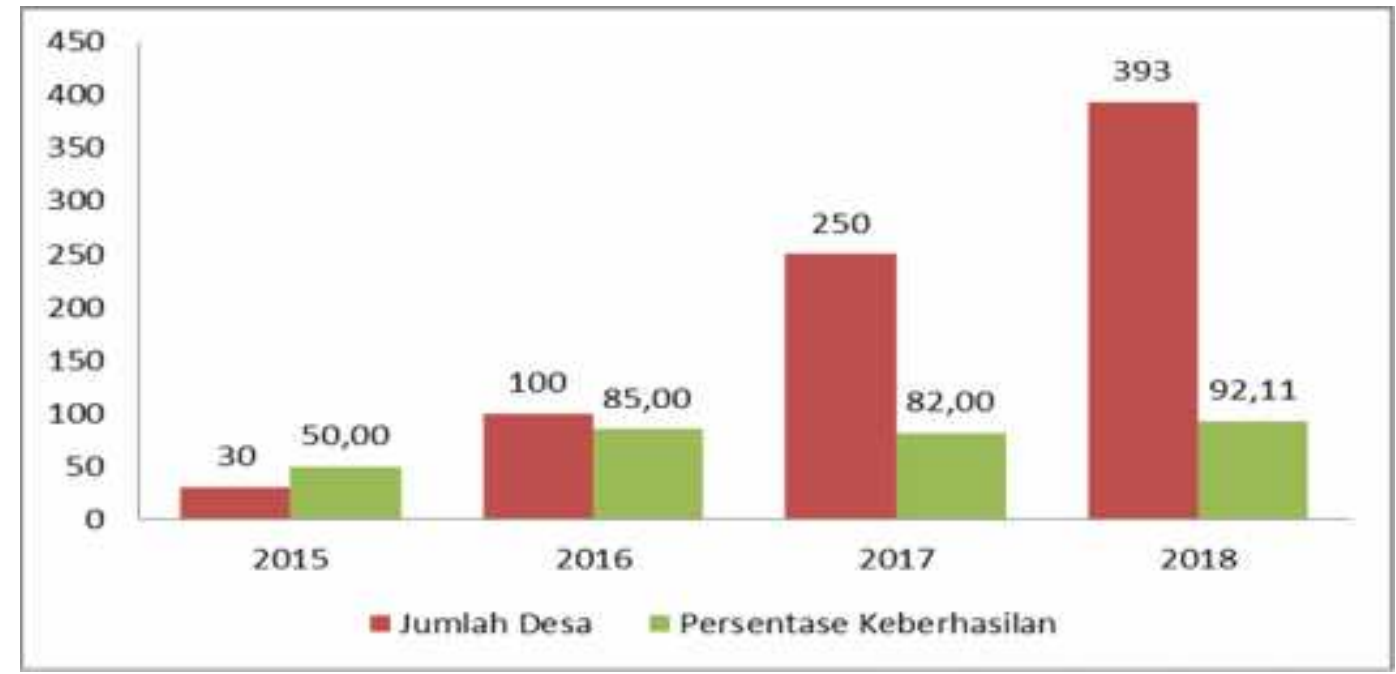

Sumber: Dinas PMD, data diolah

Gambar 1. Persentase Perubahan Status Desa Tahun 2015-2018

Persentase perubahan status desa menunjukkan bahwa Pencapaian Program Gerbang Desa Saburai berhasil, hal ini dapat dilihat dari pencapaian tersebut di atas 50 persen pada setiap tahunnya. Pada tahun 2015 terdapat 30 desa dalam program tersebut dan desa yang berubah status dari desa tertinggal ada 15 desa yaitu (50 persen) dari total desa. Pada tahun 2016 dari 100 desa terdapat 85 desa atau 85 persen berubah status. Pada tahun 2017 dari 250 desa yang memperoleh bantuan Program Gerbang Desa Saburai, terdapat 82 persen yang meningkat statusnya yang sebelumnya memiliki status desa tertinggal. Pada tahun 2018 ada 393 desa yang mendapat program terdapat 362 desa atau 92.11 persen desa yang berubah status. Hal ini menunjukkan bahwa Program Gerbang Desa Saburai berhasil karena pencapaian evaluasi setiap tahunnya lebih dari 50 persen. Hal ini disebabkan adanya sinergisitas dengan Organisasi Perangkat Daerah (OPD) dalam pelaksanaan program.

Uji F-statistik dalam penelitian ini diperoleh nilai sebesar 37,28 lebih besar dibandingkan dengan nilai F-tabel pada tingkat signifikansi $(\alpha) 5 \%$ yaitu 4,03 sehingga dan probabilita $F$ statistik 0,0000 dapat disimpulkan bahwa bantuan langsung masyarakat dan swadaya masyarakat secara bersama-sama mempengaruhi jumlah desa tertinggal. Koefisien Determinasi $\left(\mathrm{R}^{2}\right)$ menunjukkan nilai 0,6034 . Hal ini mengindikasikan bahwa $60 \%$ jumlah desa tertinggal dipengaruhi oleh bantuan langsung masyarakat dan swadaya masyarakat sedangkan sisanya $40 \%$ dipengaruhi oleh faktor lain diluar model.

Uji-t Parsial dilskuksn untuk mengetahui pengaruh dari setiap variabel bantuan langsung masyarakat dan swadaya masyarakat secara parsial terhadap jumlah desa teringgal. Dengan menggunakan signifikansi $5 \%(\alpha=0,05)$, dan df $(n-k-1)=49$ diperoleh t-tabel sebesar 1,67655. Secara parsial variabel bantuan langsung masyarakat berpengaruh negatif dan signifikan terhadap jumlah desa tertinggal, hal ini ditunjukkan dengan nilai t-hitung sebesar -6,986640 lebih besar dibandingkan dengan nilai t-tabel sebesar -1,67655 
sehingga $\mathrm{H}_{0}$ ditolak dan $\mathrm{H}_{\mathrm{a}}$ diterima. Begitu pula dengan variabel swadaya masyarakat berpengaruh negatif dan signifikan terhadap jumlah desa tertinggal

Evaluasi Siqnifikansi dana bantuan masyarakat dan swadaya masyarakat dengan upaya mengurangi jumlah desa tertinggal dilakukan uji regresi. Hasil model Random Effect Model menunjukkan bahwa nilai koefisien konstanta 3,944069 hal ini menjelaskan bahwa ketika semua variabel sama dengan nol, maka jumlah desa tertinggal sebanyak 4 desa. Sedangkan koefisien variabel bantuan langsung masyarakat sebesar 0,0983 dengan probabilitas 0,0000 lebih kecil dibandingkan dengan $\alpha=5 \%$, hal ini menujukkan bahwa bantuan langsung masyarakat berpengaruh negatif dan signifikan terhadap pengurangan jumlah desa tertinggal. Tetapi jika terjadi peningkatan bantuan langsung masyarakat sebesar 100 juta dan tidak di ikuti dengan adanya dana swadaya masyarakat maka akan menurunkan jumlah desa tertinggal sebanyak 0,09 desa atau dengan kata lain untuk mengurangi satu desa tertinggal dibutuhkan dan bantuan langsung sebanyak 1.100 juta selama periode penelitian. Hasil penelitian ini sejalan dengan penelitian Pratama (2018) bahwa kegiatan bina desa yaitu pembangunan fisik dan non fisik belum mampu mengentaskan seluruh desa tertinggal, tetapi bantuan langsung masyarakat mampu mengurangi jumlah desa tertinggal. Berbeda dengan temuan Prasetyo (2012) yang mengatakan kegiatan bina desa yaitu pembangunan fisik dan non fisik belum mampu mengentaskan desa tertinggal.

Selanjutnya koefisien variabel swadaya masyarakat sebesar -0,04733 dengan probabilitas 0,0000 lebih kecil dibandingkan dengan $\alpha=5 \%$, hal ini menujukkan bahwa swadaya masyarakat berpengaruh negatif dan signifikan terhadap jumlah desa tertinggal. Dimana jika terjadi peningkatan swadaya masyarakat sebesar 100 juta, maka akan mengurangi jumlah desa tertinggal sebanyak 0,04 desa tertinggal atau dengan kata lain untuk mengurangi satu desa tertinggal diperlukan dana swadaya masyarakat sebesar 2.500 juta. Hasil ini mendukung temuan Mohi, et all (2017) yang mengatakan bahwa peran masyarakat dalam Program Pemberdayaan Masyarakat (PNPM) berpengaruh negatif terhadap kemiskinan desa. Hasil regresi dengan model Random Effect Model seperti Tabel 4 sebagai berikut:

Tabel 2 Rangkuman Hasil Regresi'Variabel Terikat: Jumlah Desa Tertinggal (JDT)

\begin{tabular}{|c|c|c|}
\hline \multirow{2}{*}{ Variabel } & \multicolumn{2}{|c|}{ Model } \\
\hline & OLS & REM \\
\hline \multirow{2}{*}{$\mathrm{C}$} & 5,445581 & 3.944053 \\
\hline & $(2,385103) *$ & $(2,194923) *$ \\
\hline \multirow{2}{*}{ BLM } & -0.008013 & -0.098335 \\
\hline & $(0,008013)^{*}$ & $(0.001407)^{*}$ \\
\hline \multirow{2}{*}{ SDY } & -0.037550 & -0.047331 \\
\hline & $(0,009081)^{*}$ & $(0.007642)^{*}$ \\
\hline $\mathrm{R}$-squared & 0.659126 & 0.603494 \\
\hline Adjusted R-squared & 0.530146 & 0.587310 \\
\hline F-Statistic & 5.110316 & 37.28974 \\
\hline Prob (F-Statistic) & 0.000034 & 0.000000 \\
\hline Durbin-Watson Stat & 1.935569 & 2.061539 \\
\hline
\end{tabular}

Sumber: Hasil regresi diolah.

Mekanisme pembangunan desa merupakan kombinasi yang sangat apik antara kegiatan partisipasi masyarakat disatu pihak dan kegiatan pemerintah di pihak lain. Pembangunan pedesaan yang meletakkan dasar-dasar pembangunan untuk memperkuat pembangunan daerah dan pembangunan nasional. Tujuan akhir pembangunan pedesaan adalah untuk meningkatkan kesejahteraan penduduknya secara langsung maupun secara tidak langsung (Panudju 1999) 
Program Gerbang Desa Saburai ini merupakan salah satu program berbasis partisipasi masyarakat dapat berupa gotong royong. Kegiatan gotong royong dicerminkan oleh terlibatnya sejumlah tenaga kerja. Tenaga kerja yang terlibat dihitung sebagai upah yang tidak diterimakan atau dibayarkan dan dianggap sebagai swadaya masyarakat. Selain itu bentuk partisipasi lainnya berupa sumbangan dalam bentuk material seperti semen, pasir dan lain lain. Bentuk lain swadaya yang dilakukan masyarakat pada program gerbang desa saburai ini seperti pembebsan lahan dalam pembukaan badan jalan, yang mana masyarakat mampu menyumbangkan lahannnya dengan lebar dan panjang sesuai dengan ukuran badan jalan. Masyarakat tidak merasa keberatan untuk menyumbangkan lahannya, karena akan menaikkan nilai jual lahan tersebut dan membuka akses transportasi yang akan memudahkan atau memperlancar perekonomian desa tersebut. Sementara bentuk partisipasi yang dilakukan masyarakat lainnya seperti wanita yaitu menyumbangkan konsumsi seperti makan, minuman, kue-kue yang dapat dihitung sebagai swadaya masyarakat.

Upaya mengetahui kemampuan individual effek masing-masing kabupaten dikakukan Uji Individual Effect dan hasilnya disajikan pada Tabel 3 berikut ini:

Tabel 3. Individual Effect

\begin{tabular}{lcc}
\hline \multicolumn{1}{c}{ CROSSID } & Effect & Total Effect \\
\hline Lampung Selatan & 3,402963 & 7,347016 \\
\hline Lampung Utara & 2,392454 & 6,336507 \\
\hline Lampung Barat & 0,029263 & 3,973316 \\
\hline Lampung Timur & $-0,241736$ & 3,702317 \\
\hline Lampung Tengah & 1,930272 & 5,874325 \\
\hline Pesawaran & $-2,002201$ & 1,941852 \\
\hline Pringsewu & $-3,027393$ & 0,916660 \\
\hline Tanggamus & 0,096253 & 4,040306 \\
\hline Tulang Bawang & $-1,178261$ & 2,765792 \\
\hline Tulang Bawang Barat & 2,463364 & 6,407417 \\
\hline Mesuji & 1,055485 & 4,999538 \\
\hline Way Kanan & $-2,294867$ & 1,649186 \\
\hline Pesisir Barat & 1,939410 & 5,883463
\end{tabular}

Sumber: data diolah ( Eviews 9).

Hasil uji Individual Effect menunjukkan bahwa kabupaten yang memiliki efek terbesar terhadap desa tertinggal adalah Lampung Selatan dengan effect sebesar 7,347016. Hal ini menunjukkan bahwa tanpa adanya Bantuan Langsung Masyarakat dan Swadaya Masyarakat akan tetap meningkatkan desa tertinggal di Lampung Selatan sebanyak 7 atau 8 desa tertingal, karena dengan adanya bantuan langsung masyarakat dan swadaya masyarakat masih akan tetap meningkatkan desa tertinggal sebesar 7,34 desa. Begitu juga dengan kabupaten lainnya yang memiliki effect positif seperti Lampung Utara sebesar 6,33 persen, Tulang Bawang Barat sebesar 6,41 persen, Pesisir Barat sebesar 5,88 persen, Mesuji sebesar 4,99 persen, Lampung sebesar 5,87 persen, Tanggamus sebesar 4,04 persen dan Lampung Barat sebesar 3,97 persen. Efek positif tersebut mengindikasikan bahwa ada variabel lain yang mempengaruhi desa tertinggal.

Sedangkan kabupaten yang secara negatif memiliki nilai terbesar dalam hasil Cross-section Random Effect adalah Pringsewu dengan nilai -3,03. Hal ini menunjukkan bahwa bantuan langsung masyarakat dan swadaya masyarakat akan menurunkan desa tertinggal sebesar 0,92 persen. Begitu juga dengan Way Kanan sebesar 1,65 persen, Pesawaran sebesar 1,94 persen, Tulang Bawang sebesar 2,76 persen, dan Lampung 
Timur sebesar 3,70 persen. Efek tersebut mengindikasikan bahwa tanpa bantuan langsung masyarakat dan swadaya masyarakat sangat diperlukan untuk mendorong penurunan desa tertinggal.

\section{KESIMPULAN}

Partisipasi masyarakat dalam menerima dan memanfaatkan hasil pembangunan pada Program Gerbang Desa Saburai pada tahun 2015-2018 diwujukan dengan keterlibatan dalam proses perencanaan, pelaksanaan berbasis pada kelompok kerja yang di sebut pokmas. Hal ini tercermin pada waktu pemilihan jenis prasarana yang akan dibangun, masyarakat dilibatkan secara langsung dalam pemilihan prasarana yang akan dibangun, sehingga prasarana yang dibangun sesuai dengan kebutuhan masyarakat dan tepat sasaran. Dana dari swadaya masyarakat cukup menggembirakan pada tahun 2015 mencapai sebesar $11.00 \%$ dan selalu meningkat sehingga pada tahun 2018 memiliki kontribusi sebesar 17.00\%.

Secara statistik keberhasilan pemerintah daerah mengurangi jumlah desa tertinggal dipengarihi secara siqnifikan oleh tersedianya dana bantuan langsung dan swadaya masyarakat. Baik secara bersama-sama dengan uji $\mathrm{F}$ statistik maupun parsial dengan uji $\mathrm{t}$ statistik. Upaya untuk mengurangi satu desa tertinggal dibutuhkan dana bantuan langsung sebanyak 1.100 juta. Sedangkan untuk mengurangi satu desa tertinggal diperlukan dana swadaya masyarakat sebesar 2.500 juta. Kondisi ini didukung dengan proses pembangunan yang transparan melibatkan masyarakat mulai dari perencanaan sampai dengan pelaksanaan kegiatan. Ketepatan memilik kegiatan penyediaan infrastruktur desa menjadi faktor penentu keberhasilan program.

Mekanisme pembangunan desa merupakan kombinasi yang sangat apik antara kegiatan partisipasi masyarakat disatu pihak dan kegiatan pemerintah di pihak lain. Pembangunan pedesaan yang meletakkan dasar-dasar pembangunan untuk memperkuat pembangunan daerah dan pembangunan nasional. Tujuan akhir pembangunan pedesaan adalah untuk meningkatkan kesejahteraan penduduknya secara langsung maupun secara tidak langsung.

\section{DAFTAR PUSTAKA}

Alamsyah, Oleh M Nur. 2011. "Memahami Perkembangan Desa Di IndonesiaAlamsyah, O. M. N. (2011). Memahami Perkembangan Desa Di Indonesia. ACADEMICA Fisip Untad, 3(2), 647-660." ACADEMICA Fisip Untad.

Ali, Mohammad. 2009. Pendidikan Untuk Pembangunan Nasional, Menuju Bangsa Indonesia Yang Mandiri Dan Berdaya Saing Tinggi. Jakarta: Grasindo.

Badan Perencanaan Pembangunan Nasional. 2004. Tata Cara Perencanaan Pengembangan Kawasan Untuk Percepatan Pembangunan Daerah. Jakarta: Direktorat Pengembangan Kawasan Khusus dan Tertinggal. Jakarta: Bappenas.

Bappenas RI. 2015. “Rencana Pembangunan Jangka Menengah Nasional 2015-2019." Rencana Pembangunan Jangka Menengah Nasional 2015-2019.

Mohi, Widya Kurniati, Rusdin Djibu, and Yena Dunggio. 2017. "Peran Masyarakat Dalam Program Nasional Pemberdayaan Masyarakat (PNPM) Di Desa Bulontio Barat, Kecamatan Sumalata." Publik: (Jurnal Ilmu Administrasi).

Panudju, Bambang. 1999. Pengadaan Perumahan Kota Dengan Peran Serta Masyarakat Berpenghasilan Rendah. Bandung: Penerbit Alumni.

Sjafrizal. 2008. Ekonomi Regional. Teori Dan Aplikasi. Padang: Baduose Media. 